\title{
The use of woody plants in Estonian and Livonian manor ensembles during the second half of the 17th century
}

\section{Sulev Nurme}

Nurme, S. 2020. The use of woody plants in Estonian and Livonian manor ensembles during the second half of the 17th century. - Forestry Studies | Metsanduslikud Uurimused 72, 75-90, ISSN 1406-9954. Journal homepage: http:/ / mi.emu.ee/forestry.studies

\begin{abstract}
Not much is known about the 17th-century Estonian and Livonian landscape architecture. Most of the information is based on the descriptions found in historical archival and literary sources and on some of the well-known engravings. According to these, a common idea of that era's landscape architecture is that it was humble in scale and design, and was similar to the practice of late-medieval times when there was no space or ambition to grow woody plants in small gardens of castles. But when diving into the Swedish manor plans dating back to the last decades of the 17th century, it can be noted that the layouts of manorial hearts are inherent to the spatial design of early baroque, which is characterized by a landscape that has strongly been redesigned and includes a decorative garden, kitchen garden and a park. This article focuses on the spatial composition of Estonian and Livonian manor parks of the second half of the 17th century and observes the role of trees and their use in these landscapes. This article is based on the results of a study about the planning of baroque manor hearts Understanding the Role of 18th Century Estonian Manor Ensembles in Contemporary Planning and Conservation (Eesti 18. sajandi mõisaansamblid 21. sajandi maastikuplaneerimises: avastamine, mõistmine, tõlgendamine) which was carried out by the author of this article. The map analysis results deal with the spatial structure of manor ensembles and the observations made during the analysis. The article examines the possible ways of using woody plants in 17th-century Estonian manors while looking at the manor ensemble as an architectonic of early baroque. Based on the research results it can be said that by the last decades of the 17 th century the wealthiest manors had already built manor hearts with a modest but a clearly baroque style layout which is characterized by a regular and symmetrical ensemble core, a garden axially connected to the main building and avenues heading into the landscape. This type of approach enables to broaden the common conception of the era's garden and park architecture in the manor hearts of Estonia and Livonia. Based on what is highlighted in the article it can be said that the tradition and practice of garden art that has shaped the image of Estonian landscape had already been developed by the end of the 17 th century.
\end{abstract}

Keywords: manor parks, research and conservation of historic parks, trees of historic parks.

Author's address: info@sulevnurme.org

\section{Introduction}

Not much is known about the 17 th-century Estonian and Livonian manor parks and gardens. The conception of the garden art of this era is mostly based on descriptions from historical resources and single graphic images (Nurme, 2019). There are no 
materials from the 17th century with such level of detail that have been preserved of Uhtna, Palmse or Sagadi manorial hearts from the first half or middle of the 18 th century. At the same time, the plans from the 18th century help to decipher the situation at the end of the 17th century, taking into consideration the trends that had spread in Europe and especially in Sweden. Among Estonian manors today the most detailed design of gardens and parks can be seen on the 1753 plan of Palmse manorial heart (EAA 1690.1.34 Sheet 1). Another less known but still a very remarkable sketch is the 1749 design of Sagadi manor park (EAA 1324.1.141 Sheet 8.). A little bit more is known about Livonian manors, which are located nowadays in the territory of Latvia, thanks to the drawings from the end of the 18th century by Johann Christoph Brotze and Johann Wilhelm Krause. For example, detailed sketches of garden designs are preserved of Linde manor (Janelis, 2010).

The 16th century and the first half of the 17th century was troubled and destructive in Estonia and Livonia as most of the local manors and fortresses were demolished and looted during wars (Praust, 2005). Even though there are notes about the construction activities in manor hearts even from the end of the Livonian War in the 1580 s, it was mostly limited to necessary repairs (Hein, 1998). The somewhat more peaceful period was greeted in 1629 when the whole mainland of Estonia became part of Sweden with the Truce of Altmark which was signed by Sweden and Poland. This ended warfare for some time and gave an opportunity to fix and improve the manorial hearts.

While the planning of manorial hearts in the first half of the 17th century was humble and similar to the medieval fortress-type style due to economic and security reasons, a paradigmatic change occurred probably in the 1660s when the baroque style that had spread through Europe rooted in Sweden and then expanded to the provinces behind the sea, Estonia and Livonia (Nurme, 2019). Thus, the villa rustica way of thinking started to develop which was mostly expressed in the building of new or rebuilding of older wealthier manor hearts to match the new baroque spatial programme (Turner, 2011). Unfortunately, the Great Northern War that started in the beginning of the 18th century disrupted the development of manorial hearts in Estonia for more than a couple of decades, especially the restoration of manor hearts, which is why the land destroyed in the war started to show first signs of recovery in the 1730s. Based on the above, the second half of the 17th century can be considered as the earliest period of manor park development and it can conditionally be considered to have spanned from 1670 to 1700 . Unfortunately, the architectural legacy of most of the 17th-century manors, not to mention the gardens and parks, was destroyed in the Great Northern War and in the subsequent rebuilding and restorations of manorial hearts (Hein, 1998). However, this period is significant for the development of local garden art because this was the time when the specific compact baroque ensemble developed according to local conditions and woody plants had a very important role in its characteristic architectonics (Nurme, 2014).

\section{Swedish context}

Many very influential architects and gardeners of 17th-century Europe were from the Kingdom of Sweden. Some of the most well-known of them are Jean de la Vallee and his architect son Simon de la Vallee, Nicodemus Tessin the Elder and his son Nicodemus Tessin the Younger, Johan Hårleman, Christian Horleman and many more. All of them had travelled to, studied or worked in France, which is why the newest trends in garden art practice reached the Swedish noblemen's residences very quickly (De Jong, 2005). The moder- 
nity of Swedish garden art is characterized well by the fact that in 1651 Andre Mollet's Le Jardin de Plaisir was published in Stockholm and became one of the most influential theoretical approaches of garden art in the baroque era in France, the Netherlands and Sweden (De Jong, 2000). Mollet published his handbook based on his own abundant experience as the gardener in the royal gardens of the Netherlands and Sweden. The theory presented in the book had already successfully been tested in the gardens of Swedish noblemen, which is why when Andre Mollet left Stockholm in 1653 , his practice was continued by Jean de Vallee and Nicodemus Tessin the Elder (Olausson, 2005). The parterres of the royal gardens in Stockholm by Mollet became the role model for Nicodemus Tessin who designed the gardens of Drottningholm Palace in 1661 (Kluckert, 2007) ${ }^{1}$.

Thanks to the connection with Sweden, contemporary construction art reached Estonia in a broader sense already in the second half of the 17th century. The highest level of architecture in the provinces of the Kingdom was mediated by the Governor of Swedish Estonia and Governor-General of Livonia Jacob de la Gardie and after his death by his son Magnus de la Gardie. Magnus de la Gardie was very well informed with the works of Mollet and with many other contemporary theoretical works of architecture and garden art, and he often drew his own sketches for his garden design projects (Lindahl, 2004; De Jong, 2005). The modern architectural theory also reached the provinces behind the sea through local practitioners. Therefore, in the 1660s there were probably many books by Philibert de l'Orme, Vignola, Scamozzi and also the two most popular works of that era Le Jardin de Plaisir by Andre Mollet and Le Theatre des Plans et Jardinages by Claude Mollet, in the library of Jacob Stael von Holstein who was the most well-known military engineer and archi-

\footnotetext{
1 The regular park of Drottningholm in its current volume was designed by Nicodemus Tessin the Young in 1681, also see Olausson, 2005: 191-194
}

tect of the 17th century working in Estonia (Hein, 2005).

In the 1650s de la Gardie made grand plans in Põltsamaa, Haapsalu and Kuressaare. For example, in 1651 he ordered a complete rebuilding project for the Kuressaare Castle from Nicodemus Tessin the Elder, according to which the medieval fortress would be turned into a palace with beautiful gardens (Maiste, 2007). The rebuilding designs of Haapsalu fortress by Matthias Holt turned the fortress into one of the noblest residences in Sweden (Hein, 2005). Swedish noblemen who had many territories in Estonia and Livonia, which were given to them for their service in war, made lavish plans for building castles also in other places but due to the restless political and economic events of that century they remained fancy sketches and were realized only in a humble form or in larger country manors, such as Kolga, Malla, Raasiku, Lihula or Matsalu (Hein, 2005).

Similarly to the contemporary European villa culture in construction (Aben \& de Wit, 1999), the 17th-century Baltic-German manor architecture can be characterized by the growing importance of the volume of the unfortified main building in the manorial heart (Pirang, 1926); the enclosed main building as a fortress (chateau fort) was replaced by the open chateau plaisance (Hein, 2005). Due to the increase in the use of firearms, fortified manorial hearts lost their importance, which is why many of them were never rebuilt after the Livonian War (Maiste, 2005). The ruins were replaced by new buildings, such as Vana-Antsla or Kasti manor (Tuulse, 1942), or a new manor heart was built next to the old one, for example in Porkuni, Suure-Rõngu or Lihula (Tuulse 1942), or it was built in a completely new location, which was chosen on the one hand based on the location of fertile arable lands (Tarkiainen, 2009), and on the other hand according to the physical traits of the location - it would have to support the spatial logic necessary for achieving a representative baroque ensemble. 

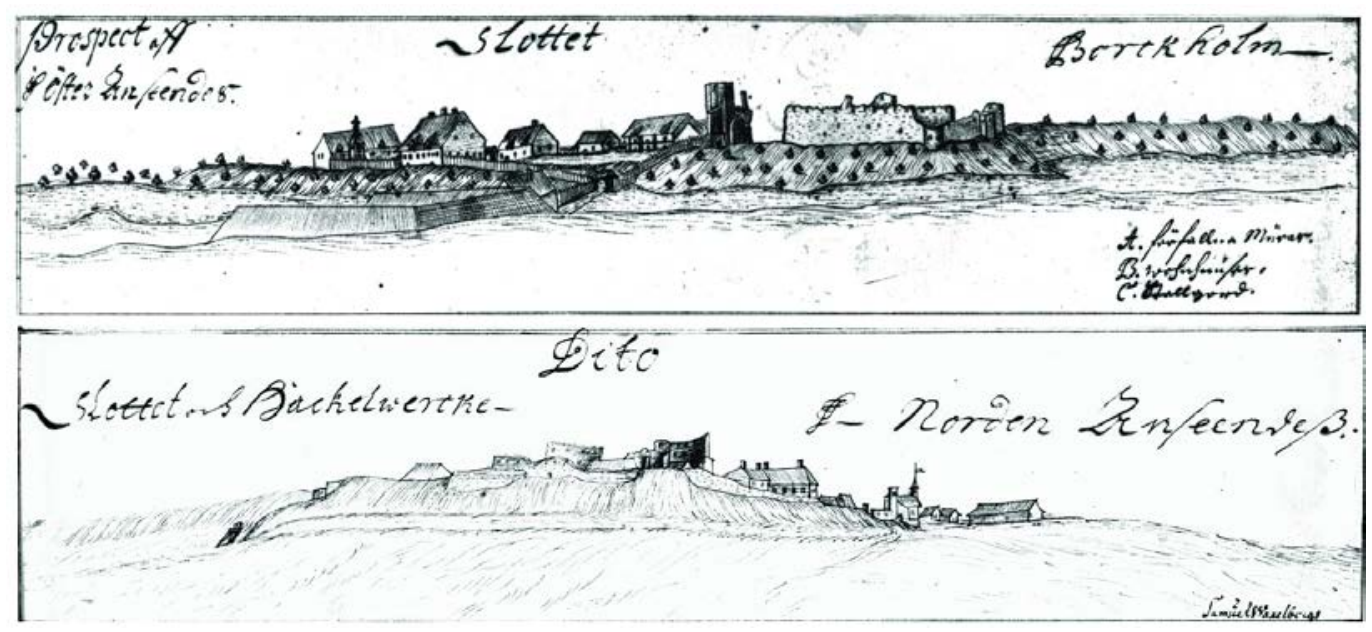

Figure 1. Views of Porkuni (above) (TÜR KAF 37591) and Lihula Manorial core in 1683 (TÜR KAF 39024) drawn by Samuel Waxelberg.

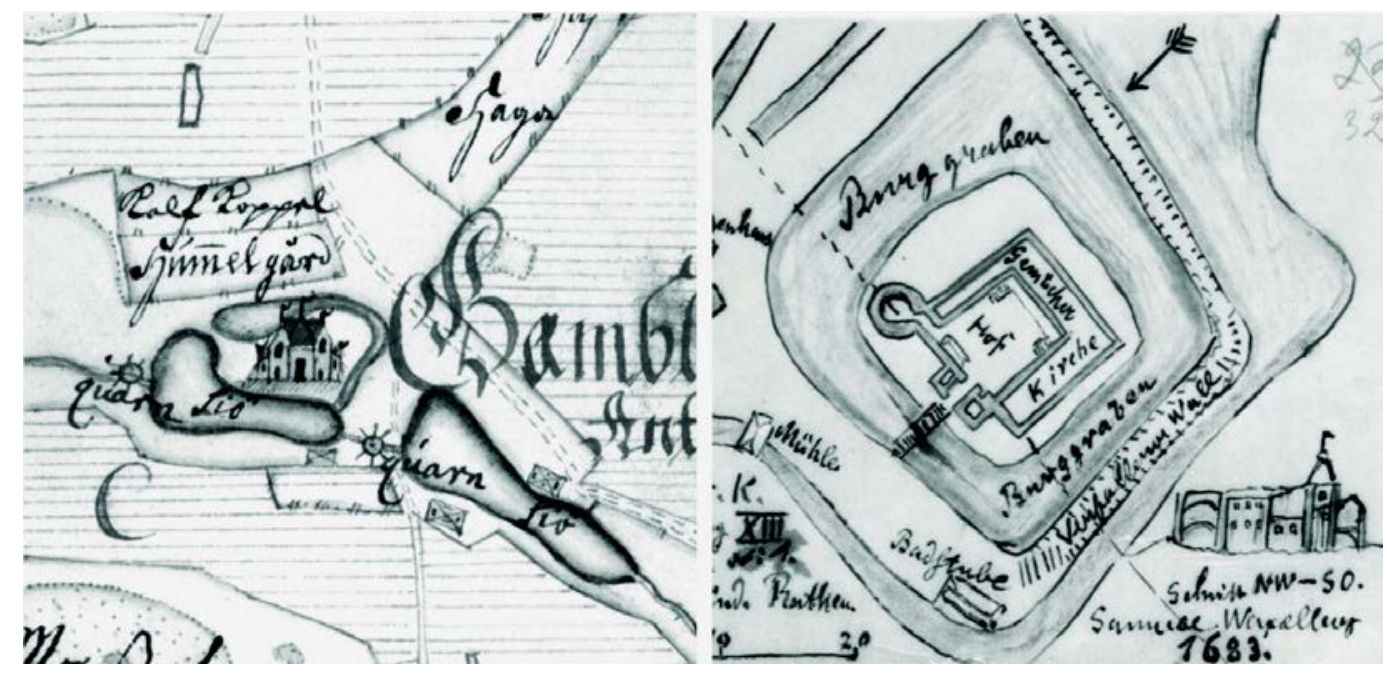

Figure 2. On the left: Manorial core of Vana-Antsla in 1688 (EAA 308.2.186 Sheet 1). The position of the manor core is set by the moat and artificial lakes. On the right is a plan of Koluvere manorial core (EAA 854.4.469 Sheet 32): the position of the manorial core is set by the fortified residence and fortifications connected to it (moat, entrenchment), also by the access to the fortified residence and river that was flooded for the purpose of protection.

For example, the manor in Kuremaa has a Palladio-like architectural style which took into account the surrounding picturesque landscape and Kuremaa lake. Construction started already in 1684 and was based on the project by Jacob Stael von Holstein (Hein, 1998). At the same time, the European or Swedish experience was not directly adapted but it was experimented with and conformed according to the local conditions taking into consideration the Baltic German cultural context, economic means and local climate (as Swedish climate is very different from French climate). Therefore, before the Great Northern War even the most successful manorial hearts re- 
mained significantly humbler than the villas of the motherland, the Swedish Kingdom (Spārītis, 2009).

\section{Layout of the manorial heart in the changing 17th century}

The 17th-century manorial hearts, in general, remained modest (Hein, 2005; Ränk, 1971). The buildings and layout of manorial hearts stayed down-to-earth and practical, buildings and fences were as a rule made of wood (Maiste, 2005). Until the beginning of the second half of the 17th century the manorial hearts were built and restored in the spirit of the traditional so-called Frankish fortress-type style that dates back to the early medieval times in the old German culture and it is characterized by a compact, enclosed courtyard which is surrounded by buildings on the perimeter (Pirang, 1926). The most important building - the dwelling house - was usually located in the southeast or southwest, although the most prominent building was the manor - the nobleman's dwelling house, which was surrounded by numerous outbuildings for management and a garden (Ränk, 1971). They had a functional layout and were poorly or not at all connected to each other as an ensemble (Nurme, 2014). This type of layout can be noted on many of the earlier plans of Livonian manor hearts of that era (Janelis, 2010; Nurme, 2014; Mašnovskis, 2018). For example, on the 1648 Lokuta manor plan (Hein, 2005: 210-211), a manorial heart with a central open square surrounded by buildings, two fenced gardens and another fence can be distinguished. This can also be seen on the well-known engraving of Kunda manor heart by Adam Olearius made in 1647 (TÜR KAF 4714). Based on historical views and plans of that era, it can be assumed that vegetation from the point of view of the ensemble as the architectonics was not important and was limited mostly to naturally grown vegetation around the manorial heart and inside its kitchen garden. The latter originating from medieval times also fulfilled the function of a decorative garden (Ränk, 1971). Based on the above, it can be said that in the mid-17th century there was no knowledge about the baroque ideas spreading in Europe or opportunities for implementing them in manorial hearts (Nurme, 2019).

The basic principal change can be noted in the 1670s and 1680s. Therein, a significant event was the construction of Maardu manorial heart in the 1660s designed by Jacob Stael von Holstein, which strongly differed with its Palladio-like architectural style from the residences of Swedish noblemen in Malla, Kolga or Varangu built in the mid-17th century (Hein, 1996). On the 1692 plan of Maardu manor (EAA 1.2.C-III-11 Sheet 1) the baroque ensemble space is not clearly visible but when observing the 1690 plan of Raasiku manor plan (EAA 1.2.C-III-37 Sheet 1) or the 1691 plan of Kangla manor (EAA 1.2.C-III-41 Sheet 1) it is clear that the spatial programme is clearly in the baroque style, having a characteristic spatial structure connected to the central axis, its core formed by the main building, an open courtyard in front of it and a decorative garden behind it (Nurme, 2019). The previously mentioned spatial structure, similar to Raasiku manorial heart, can also be seen on the 1692 and 1693 plans of Anija manor (EAA 1.2.C-III-50; EAA 1.2.C-IV37 Sheet 1), on the 1701 plan of Matsalu (EAA 1.2.C-IV-196 Sheet 1) and elsewhere. When analysing the manor plans of that era the endeavour to highlight the central axis is often visible. This was executed in the landscape with a straight road approaching the main building on the central axis and in order to achieve that the local roads needed to be redesigned to a greater or lesser extent. It was also characteristic to try to assemble the outbuildings and manor house around the frontcourt as a U-shaped group, which can be noticed on the layout as an endeavour to be corps de logis. It is also characteristic of the ensembles 


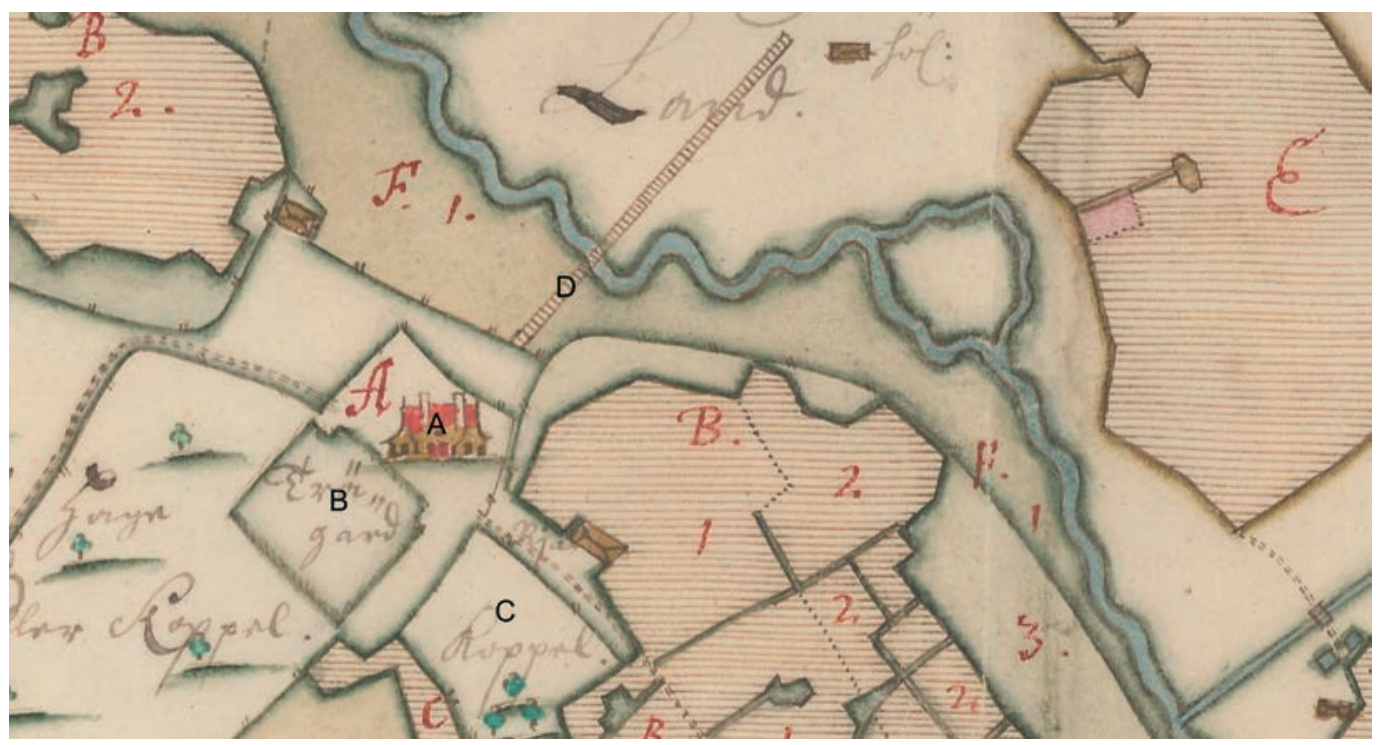

Figure 3. Raasiku Manor in 1690 shows a typical Estonian early baroque villa concept: A - main building with courd'honneur, $\mathrm{B}$ - gardens; $\mathrm{C}$ - paddock for horses with its location directly near the ensemble is quite typical of Estonian manor planning in the 1680-90s; D - main road with alley. The main axis is clearly highlighted with the alley which is designed in this place for aesthetic reasons (EAA 1.2.C-III-37 Sheet 1).

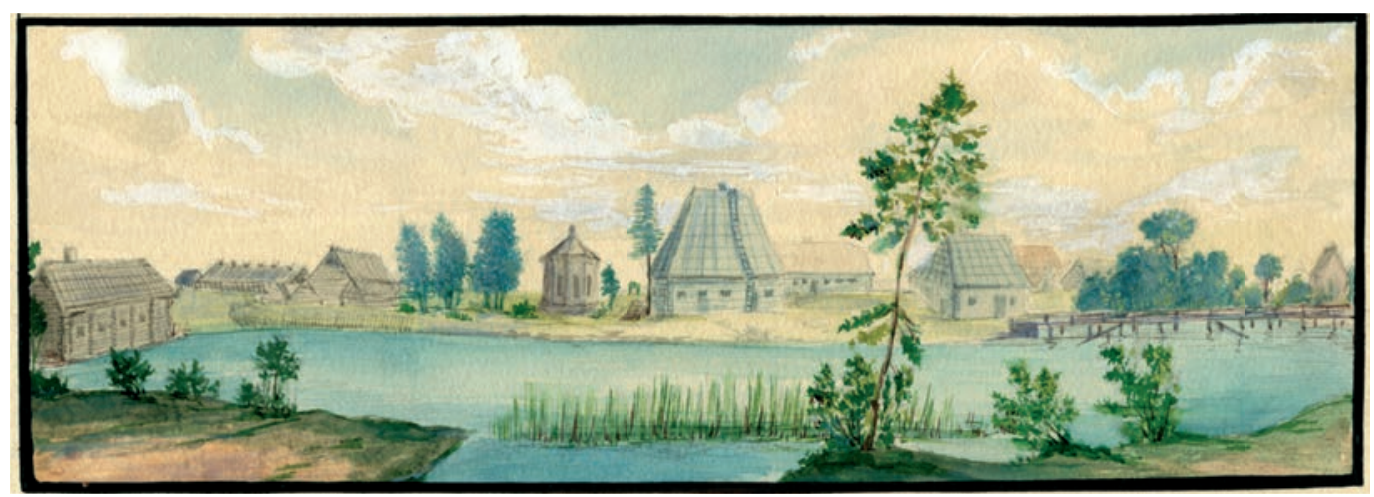

Figure 4. Vasula Manor core in 1783 by Carl Otto von Gyllenschmidt (AM 4646:21 G 6930).

that the decorative garden behind the main building takes into consideration the dimensions of the main building, which varied greatly in different manors. The planning of manor hearts greatly depended on the topography and on the manor owner's financial means to reshape the landscape keeping in mind the ambitions of the baroque ensemble. When the manorial heart was restored at the same place where the medieval manor heart had been located or nearby, then the fortifications defined the architectonics of the new manor heart and its character: mostly the locations of buildings and different parts of the garden, their axial orientation, views, the order of spaces in the ensemble, hierarchy, etc.. Most of the time the surroundings of the fortified building failed to enable building a wholesome baroque ensemble due to lack of 
space, which is why parts of the ensemble were planned in regions where the necessary space existed and therefore it was often not possible, for example, to axially connect the garden with the main building as is inherent to the baroque style. Manorial ensembles that had preserved the volume of their medieval fortified manorial heart after the Great Northern War, for example Vana-Põltsamaa (EAA 308.2.213 Sheet 1), Laiuse (EAA 2072.3.41a Sheet 4, folio III) or Koluvere (EAA 854.4.469 Sheet 32) were planned pursuing the spatial hierarchy as close to the era as possible by forcing the different parts of the ensemble view-wise to one continuous direction but due to the peculiarities of the existing buildings and fortifications the axisymmetric structure of the ensemble was not achieved (Nurme, 2019).

There were no topographic limitations in the new manorial hearts of Maardu, Kuremaa, Raasiku, Palmse and others, which is why their layout prior to the Great Northern War principally reminds a classical baroque spatial model of balti villa rustica that had developed by the mid-18th century (Nurme, 2019). What a manorial heart of that era could look like can be seen in the engravings of Espelunda manor by Erik Dahlberg (Dahlberg 1698-1715: Book II, 52) and in the watercolour painting of Vasula manor in 1783 by Carl Otto von Gyllenschmidt (AM 4646:21 G 6930). On the forefront of the view a court of honour and the main building can be seen behind the buildings on the side, whereas on the left side of the view between the trees, there is thought to be a garden pavilion with a circular-shape (Pirang, 1926). On the 19th-century plan (EAA 2072.5.483 Sheet 1) the regular part of the park behind the main building cannot distinctly be seen on the watercolour painting and the massive greenery next to the bridge leading to the frontcourt is most likely the natural vegetation on the opposite shore.

\section{Trees in the service of the baroque spatial programme}

In the spatial setting of the baroque villa ensemble in the landscape the plants, primarily trees, have quite a significant role. From the standpoint of the ensemble as a meaningful wholesome space, tree plantings marked the centre of the manorial ensemble - the building complex and park - with the borders marking the main axis in the landscape and side-axes connecting to it (Nurme, 2019) and defining the spatial structure of the park. Based on the 17th-century manor plans it can be said that the primary spatial design function of planted trees was to mark the park area and the main axis and divide the park into different sub-areas. It should be taken into consideration that most likely there were not enough financial means and the reduction of 1682-1700 (Vahtre \& Laur, 2003) ${ }^{2}$ made the interest of large scale developments and reshaping of the terrain subside and the local topographic situation defined the borders and look of the park.

The park was built on the arable land, meadow or pasture surrounding the main building or quite often was redesigned from neighbouring forests (Tarkiainen, 2009). Although these gardens in their size and expressiveness were not comparable to the grand parks of French, Dutch or Swedish manors, the decorative garden with orchards, shrubs, kitchen gardens and flower-beds that followed the composition dictated by the main building became a standard part of the ensemble (Maiste, 2005; Sinijärv, 2009). The garden of that era probably remained a mixture of a functional and decorative garden. On the one hand this was due to the geopolitical situation mentioned above, but on the other hand due to practical calculations and the Baltic German cultural tradition according to which a garden needs to be both beautiful and useful. Herein, it is important to mention two local handbooks about gardening

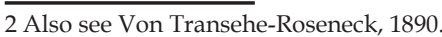


printed in the 1680s in Riga (Hein, 2007), in which the author Gregorius Franciscus Holyk references the above-stated principle (Holyk, 1709) and which portrays the wider interest in gardening. The first publication was Lieff- und Außländischer Garten-Bau (1684) and as can be read from the first chapter of the book (Holyk, 16913) does not deal with "quinquinx $x^{4}$, squares and other shapes that trees should be planted as" but deals with the agricultural engineering of fruit trees. The second book is called Versprochenes Bluhmen- und Küchen-GartenBüchlein/Worinnen Kürtzlich/doch gründlich die Handgriffe gezeiget werden $(1687)^{5}$ and it focuses on the agricultural engineering of flower and vegetable gardens, but also gives advice on planting schemes (Holyk, 1709).

As can be seen on the manor plans originating from the 17th century the space of the ensemble was split into two by the cross axis of the main building of which $1 / 3$ to half was formed by the frontcourt and the rest by gardens and the park. According to the common practice of that era the park was divided into two volume-wise contrasting parts: an open backcourt and an enclosed park area with trees planted in such manner that it looks enclosed. The park's position and structure were generally based on the longitudinal and cross axes of the main building and/ or the diagonals connected to the intersections of axes (Nurme, 2019). At the end of the 17th century, it seems that the Estonian and Livonian practice saw the enclosed part of the park often humble or missing, as is evident on the plan of Anija manor (EAA 1.2.C-III-50 Sheet 1).

The garden art tradition was carried on, similarly to Europe, in Estonia also by Cistercian monasteries which is why many earlier gardens in the North and South of Estonia were located in their vicinity 3 Herein, the quote originates from the book printed in Hamburg in 1691

4 quinquinx - planting scheme with five points, mostly used for fruit trees, known already from the medieval times

5 Herein, the reference originates from the book printed in Frankfurt and Leipzig in 1709
(Ränk, 1971). Therefore, typical gardens of the 17th century were the gardens of manor hearts and monasteries preserved as fortresses (for example Porkuni, Lihula, Põltsamaa, Padise). The gardens located next to monasteries and fortresses were not axially connected to the buildings but in general were divided into square-shaped quarters pursuing a symmetrical structure (Nurme, 2014). Functional gardens dominated (orchards, gardens for medicinal plants and herbs, vegetables, Humulus and bleaching fabrics) and probably avenues or rows of fruit trees were used (Tallinn, 2016). Roses, carnations, tulips and narcissi were grown in decorative gardens and pavilions, and gazebos and small mowed grass areas could be found (Ränk, 1971). A guideline on how to build an orchard, flower, Humulus or grape garden can also be found in the previously highlighted handbook by Gregorius Franciscus Holyk (Holyk, 1709). According to the 1686 inventory of Viimsi manor, the garden was divided into 12 quarters where vegetables, fruit trees and flowers were grown, and roads were bordered by currant bushes (Tarkiainen, 2009). Unfortunately, on the 1689 plan (EAA 1.2.C-II-35 Sheet 1) the division into quarters is not visible, but it gives an idea of the general volume of the garden and of the fish pond mentioned in two inventories which were located in the northern part of the garden and symmetrically to the longitudinal axis of the garden. Only some of the manorial hearts with preserved buildings at the end of the 17th century, such as Vana-Pääla, Suure-Rõude, or Välgita, had small-scale garden parks that were located behind or to the side of the main building. For example, on the 1687 plan of Vana-Kasti manor the orchard is clearly distinguishable as a separate structure (EAA 1.2.C-IV-240 Sheet 1). A similar orchard or decorative garden is depicted on a 1695 plan of Rosbekis Manor which is currently located in Latvia (Janelis, 2010).

Supposedly, fruit trees and decorative trees were used for planting in rows and 


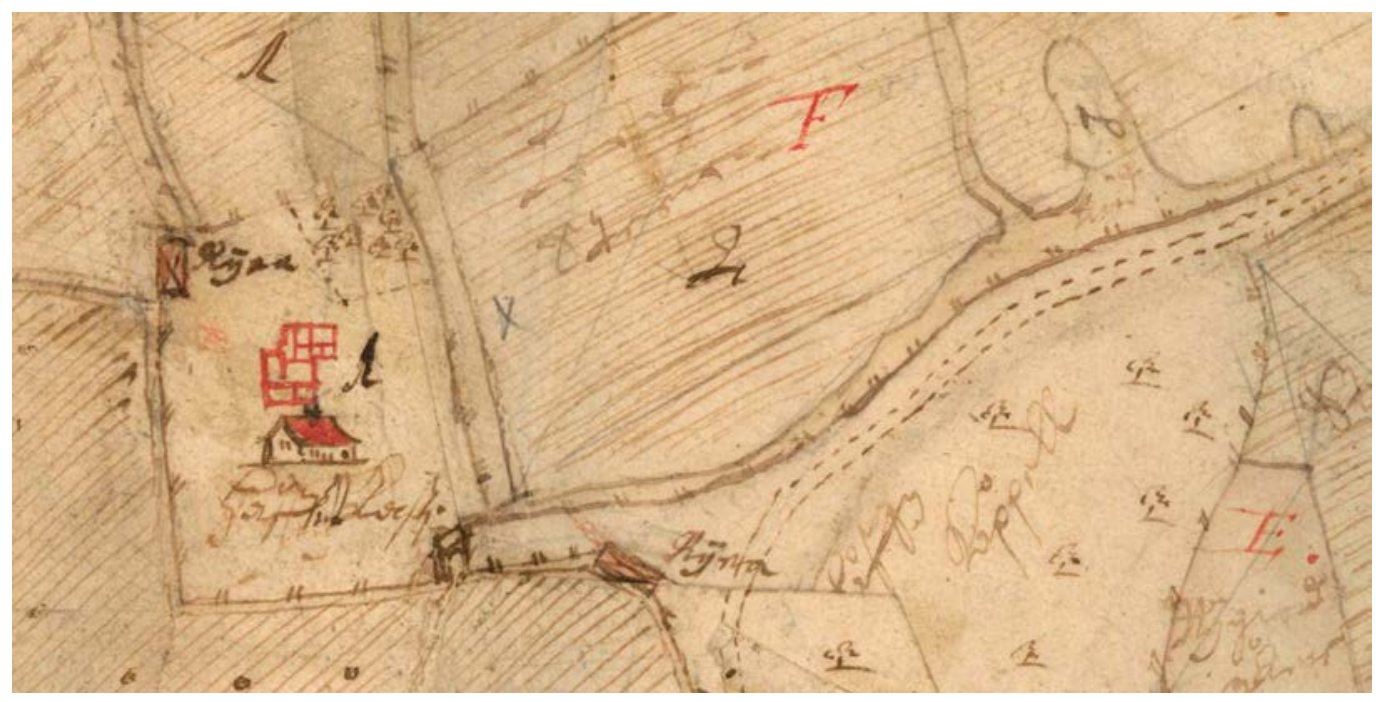

Figure 5. Kasti Manor core in 1687. On the map is shown the location of an old fortress and the new main building, also a small rectangular garden in the upper part of the manor core. (EAA 1.2. C-IV-240 Sheet 1).

in avenues (Hein, 2007). Tilia cordata Mill. is one of the few native species that can be cut into shapes without complications in the northern climate and thus, the use of Tilia in manor garden design as rows of trees became widespread in Sweden (initially Tilia cordata and starting at the end of the 17th century the imported Tilia $x$ europaea L.) (Bengtsson, 2005). From Sweden the use of Tilia probably spread to the provinces overseas. Based on the dendrological research of historical parks it can be said that the most common species in Estonian manor parks is also Tilia cordata (Nutt, 2017) but probably due to the lack of materials other available plants were not rejected and according to the common theory other suitable native deciduous trees were used, which included Ulmus glabra Huds. and Quercus robur L. (Couch, 1992). However, based on the preserved older avenues Acer platanoides L. and Fraxinus excelsior L. were also not rejected. At the same time, the local climate did not allow using the many tree and shrub species popular during the baroque era in the garden art of central and western Europe. Species such as Buxus sempervirens L., Carpinus betulus L., Taxus baccata L., Fagus sylvatica L., Cupressus sp. and many others (Wimmer, 2001) are not frost resistant in Estonia. Therefore, they were replaced by fruit trees and shrubs and other cold bearing native species such as Caragana arborescens Lam., Berberis vulgaris L., Picea abies (L.) H. Karst., and even Vaccinium vitis-idaea L. (Hein, 2007). Thus, the local topiary art remained humble in the 17th century and later on (Nurme, 2019).

Usually, the roads leading up to the manor were designed as avenues. The perimeter of the manor ensemble and primarily the park were designed with rows of trees. The park space was also divided into 4 or more quarters with rows of trees and as a result, the park with an avenue on the border perimeter was established with intersecting avenues forming rectangular shapes (Nurme, 2019). Only few illustrative map materials have preserved from the 17th century garden and park architecture, but some of the older plans preserved from the first half of the 18th century give an idea about manor parks at the end of 17th century, for example Orina (EAA 46.2.234 Sheet 1) or Uhtna (EAA 


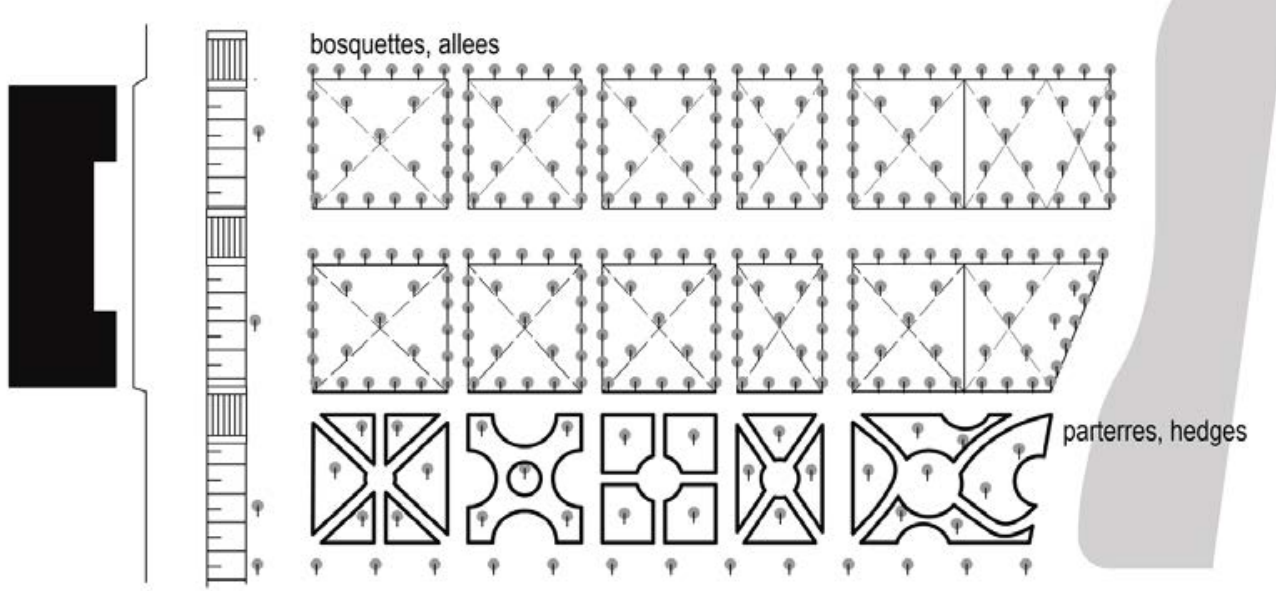

Figure 6. Garden detail from Birini Manor (Livonia) in the 1780 s, reconstruction according to a sketch by Johann Wilhelm Krause. Upper section plantings were planned as a quincunx-ornament; the lower section displays different types of ornamental plantings (Nurme, 2019).
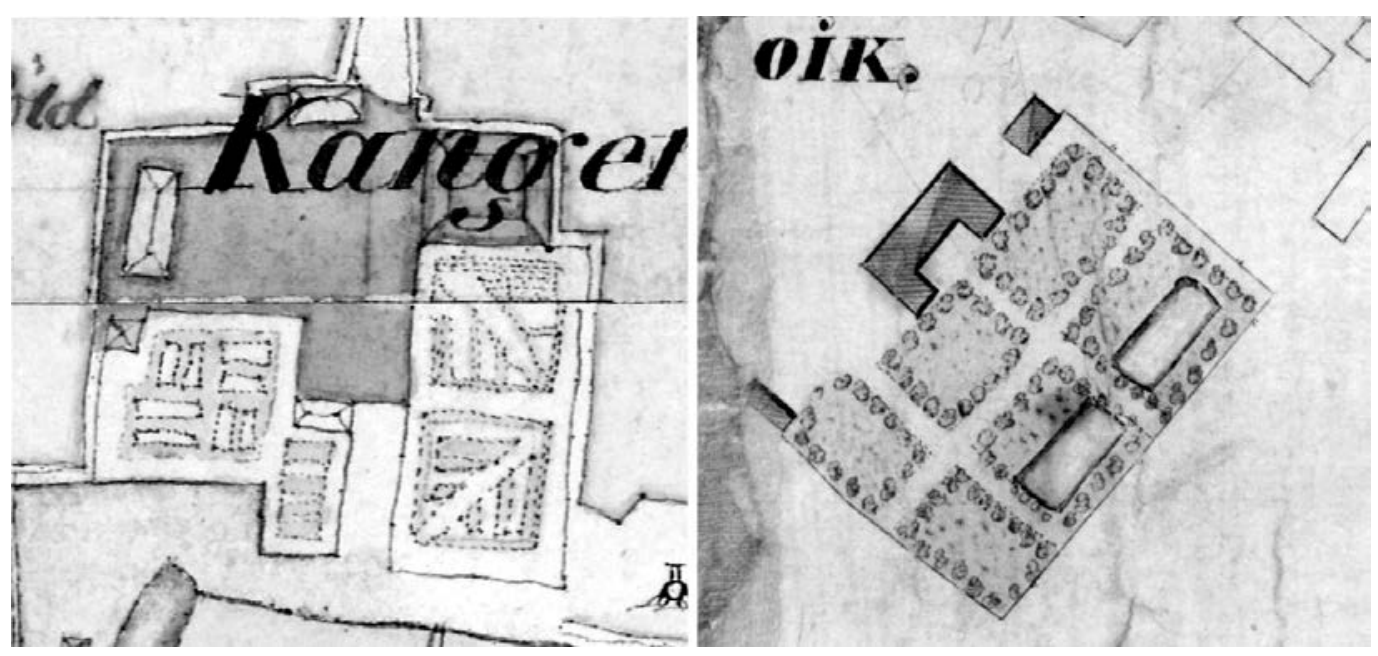

Figure 7. Examples of garden design elements. On the right is a plan of Koigi Manor Park bosquettes in 1800 (EAA 2072.5.49 Sheet 1). On the left is a plan of Kangruselja Manor Park parterres in 1790 (EAA 2072.3.426e Sheet 30).

46.2.200 Sheet 1) manor. A good overview of different planting schemes of deciduous trees is given by several Livonian manor plans drawn in the 1780 s by Johann Wilhelm Krause (Janelis, 2010; Nurme, 2019). It is impossible to say which plants were used in the parterres or flower gardens because there is no map material preserved about them from the 17 th century, and today their traces have disappeared from the parks. Based on the garden art theory of that era and single subsequent examples of the 18th century it can be assumed that wealthier places used a broderie motif for patterns inherent to the baroque style, and they were created as low hedges and topiaries (Nurme, 2019). In general, the design of flowerbeds remained simple and downto-earth as can be seen on the view of Skottorp manor in 1680 by Erik Dahlberg 


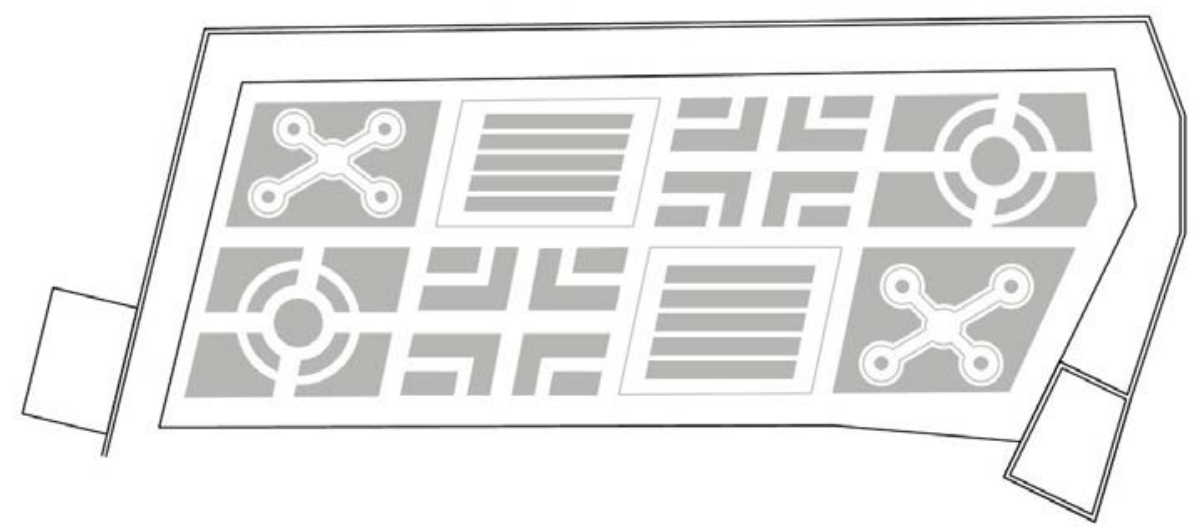

Figure 8. Reconstruction of the general layout of Cesis Castle gardens. The reconstruction above is based on a partially damaged map from the 1690s (see also Janelis, 2010).

(Dahlberg, 1698-1715: III, 108) and on the Kangruselja manor plan which is nearly a century older (EAA 2072.3.426e Sheet 30; 2072.3.426e Sheet 32).

Obviously Estonian and Livonian manor hearts were much simpler than what was recommended in the garden art theory of that era but in single cases, such as is shown on the 1690 plan of the garden complex next to the Cêsis fortress, complicated parterres and bosquettes were created in the spirit of the era (Janelis, 2010).

\section{Traces of the 17th-century garden art}

Latvian art historian Ojārs Spārītis has highlighted that even though the local manor culture in Livonia somewhat decreased the influence of the Swedish culture, then at the end of 17th century many Swedish examples were used as role-models (Spārītis, 2009). Therefore, the architectural language in wealthier manors before the Great Northern War might have been very true to the era despite the context of the era and the status of the borderlands. The reason why such lavish manor complexes that were built in Sweden, which can be seen on Erik Dahlberg's Suecia Antiqua et Hodierna, were never built in Estonia can be explained by the fact that the intensity of construction decreased after the Swedish-Russian and Swedish-Polish military conflicts occurred in the 1650s. This created insecurities in the Swedish noblemen about the unstable conditions on the eastern border (Hein, 1998) and the reduction of the last decades of the century lowered the interest in developing manor hearts. However, by the end of the 17th century, approximately a hundred manors had their main building built from stone (Hein, 1998). Ideas discussed in the article give reason to assume that next to representative manor hearts, parks and gardens were built that were designed in the spirit of the era, and their design, architectural language and practice became the basis for the 18th-century manor parks. During this short period, the baroque spatial programme was tested in local landscapes and it took into consideration the local conditions. In the manor hearts of Ohtu, Triigi, Maardu, Palmse, Pilguse and many others that had been brought to life in the spirit of villa rustica before the Great Northern War a compact baroque ensemble type, which used clear spatial forms and relatively small areas and was influenced by Nordic baroque, was created. This type characterizes Estonia and Northern Latvia. The parks built next to manorial hearts were characterized by a simple, geometric planting scheme and rational use of suitable plants that adapt well in the local climate 
conditions - all of this pleases the eye even today in many of the significant and older Estonian manor parks. In conclusion, it can be said that the second half of the 17th century became pioneering in the manorial garden art despite the fickle background.

\section{References}

\section{Publications}

Aben, R., de Wit, S. 1999. The Enclosed Garden: History and Development of the Hortus Conclusus and Its Reintroduction into the Present-day Urban Landscape. Rotterdam, 010 Publishers. 256 pp.

Bengtsson, R. 2005. Variation in common lime (Tilia $x$ europaea L.) in Swedish Gardens of the 17th and 18th centuries. - Doctoral thesis. Alnarp, Swedish University of Agricultural Sciences, Acta Universitatis Agriculturae Sueciae, $64.42 \mathrm{pp}$.

Couch, S.M. 1992. The practice of avenue planting in the seventeenth and eighteenth centuries. Garden History, 20 (2), 173-200.

Dahlberg, E. 1698-1715. Suecia Antiqua et Hodierna. Book II. National Library of Sweden. [WWW document]. - URL https:// suecia.kb.se/. [Accessed 30 November 2019].

Dahlberg, E. 1698-1715. Suecia Antiqua et Hodierna. Book III. National Library of Sweden. [WWW document]. - URL https:// suecia.kb.se/. [Accessed 30 November 2019].

De Jong, E. 2000. Nature and Art: Duch Garden and Landscape Architecture 1650-1740. Philadelphia, University of Pennsylvania Press. 264 pp.

De Jong, E. 2005. Of plants and gardeners, prints and books: Reception and exchange in Northern European garden culture, 1648-1725. - Conan, M. (ed.). Baroque Garden Cultures: Emulation, Sublimation, Subversion. Washington DC, Dumbarton Oaks, 37-84.

Hein, A. 1996. Palmse. Tallinn, Hattorpe / Eesti Entsüklopeediakirjastus. 239 pp. (In Estonian).

Hein, A. 1998. Manor architecture in Estonia during the Swedish era: evaluations and re-evaluations. (Rootsiaegne mõisaarhitektuur Eestis: hinnangud ja ümberhinnangud). - Studies on Art and Architecture / Kunstiteaduslikke Uurimusi, 9, 98141. (In Estonian with English summary).

Hein, A. 2005. Manor architecture during Swedish times, Jacob Stael von Holstein and Palladionism in Estonian architecture, manor architecture in the early and mid-18th century. (Mõisaarhitektuur Rootsi ajal, Jacob Stael von Holstein ja palladionism Eesti arhitektuuris, Mõisaarhitektuur 18. sajandi algul ja keskpaigas). - Kodres, K. (ed.). History of Estonian Art. 2, 1570-1770. (Eesti kunsti ajalugu. 2, 1570-1770). Tallinn, Estonian Academy of Arts, 209-249. (In Estonian with English summary).
Hein, A. 2007. Garden and time. Outlines from Estonian garden art history. (Aed ja aeg. Piirjooni Eesti aiakunsti vanemast ajaloost). - Lutsepp, E. (ed.). Estonian Parks 1. (Eesti pargid 1). Tallinn, Ministry of the Environment / National Heritage Board / Varrak, 17-87. (In Estonian with English summary).

Holyk, G.F. 1691. Domestic and foreign garden design. (Lieff- und Außländischer GartenBau /.../ Hamburg). [WWW document]. URL - http://resolver.sub.uni-goettingen.de/ purl?PPN626677254. [Accessed 14. March 2019]. (In German).

Holyk, G.F. 1709. Flower and kitchen garden booklet, in which the guidelines are shown quickly but thoroughly (Versprochenes Bluhmen- und Küchen-Garten-Büchlein, Worinnen Kürtzlich, doch gründlich die Handgriffe gezeiget werden. /.../. Ritschel Buchhl). [WWW document]. URL - http:// https://books.google.ee/books?id= E6AAAAcAAJ\&dq=Holyk. [Accessed 14. March 2019]. (In German).

Janelis, I. 2010. Manor Gardens and Parks of Latvia. Riga, Neptuns. 304pp.

Kluckert, E. 2007. European Garden Design: From Classical Antiquity to the Present Day. Köln, Könemann. 496 pp.

Lindahl, G. 2004. The Swedish pleasure garden (1650-1700): Ventures between classical recreation and a protestant work ethic. - Garden History, 32 (2), 167-187.

Maiste, J. 2005. Manorial Architecture in Estonia. Tallinn, Tallinna Raamatutrükikoda. 454 pp. (In Estonian with English summary).

Maiste, J. 2007. Estonian Art History. (Eesti kunsti lugu). Tallinn, Varrak. 519 pp. (In Estonian).

Mašnovskis, V. 2018. Latvian Manors. History, Architecture, Art. I. (Muižas Latvija. Vesture, arhitektura, maksla. I). DUE dizains. 311 pp. (In Latvian).

Nurme, S. 2014. Estonian baroque manor gardens today: Discovering, understanding, conservation. - Valk, M. (ed.). Proceedings of the International conference "Kadriorg 295 a baroque park nowadays". Tallinn, Asutus Kadrioru Park, 142-158. (In Estonian with English summary).

Nurme, S. 2019. Understanding the role of 18th century Estonian manor ensembles in contemporary planning and conservation. - Doctoral thesis, 32/2019. Tallinn, Tallinn University of Technology. $246 \mathrm{pp}$.

Nutt, N. 2017. The restoration of nationally protected Estonian manor parks in the light of the florence charter. - Thesis on Civil Engineering F64. Tartu, Tallinn University of Technology (School of Engineering, Tartu College). 160 pp.

Olausson, M. 2005. The aesthetic and social reception and development of the baroque garden in Sweden. - Conan, M. (ed.) Baroque Garden Cultures: Emulation, Sublimation, Subversion. Washington DC, Dumbarton Oaks, Trustees for Harvard University, 183-212. 
Pirang, H. 1926. Baltic Manor House I. The Oldest Time until around 1750. (Das Baltische Herrenhaus I. Die älteste Zeit bis um 1750). Riga, Jonck \& Poliewsky. 80 pp. (In German).

Praust, V. 2005. Manors of Harju County. (Harjumaa mõisad). Tallinn, Tänapäev. 191 pp. (In Estonian).

Ränk, G. 1971. The older Baltic Manors in Estonia. (Die Älteren Baltischen Herrenhöfe in Estland. Eine bauhistorische Studie). Uppsala, AB Lundequistska Bokhandeln. 211 pp. (In German).

Sinijärv, U. 2009. Time and space: in Estonian manor parks. - Randla, A. (ed.). Time and Space: Towards a New Heritage Conservation. Tallinn, Estonian Academy of Arts, proceedings no 19, 56-66. (In Estonian with English summary)

Spārītis, O. 2009. Some aspects of cultural interaction between Sweden and Latvian part of Livonia in the 17. century. - Baltic Journal of Art History, 79-104.

Tallinn, T. 2016. Of Estonians gardens and landscapes in 17 Century. (Rootsi aja maastikest ja aiakunstist). - Tammet, T. (ed.). Almanac of Estonian Parks no 4. (Eesti parkide almanahh 4). Tallinn, Ministry of the Environment, National Heritage Board, 40-43.

Tarkiainen, Ü. 2009. Manors in Estonian Settlement: A Historical View. (Mõis Eesti asustuspildis XVII sajandil). - Külvik M., Maiste J. (eds.). Park is Pardise in Art and Nature. (Park on paradiis looduses ja kunstis). Tartu, University of Life Sciences, 84-93. (In Estonian).

Turner. T. 2011. European Gardens: History, Philosophy and Design. London, Routledge. $411 \mathrm{pp}$.

Tuulse, A. 1942. The Castles in Estonia and Latvia. (Die Burgen in Estland und Lettland). Tartu, Dorpater Estnischer Verlag / Õpetatud Eesti Selts. 427 pp. (In German).

Vahtre, S., Laur, M. 2003. Estonian History IV. (Eesti ajalugu IV). Tartu, Ilmamaa. 311 pp. (In Estonian).

Von Transehe-Roseneck, A. 1890. Landlords and Peasants in Livonia in the 17th and 18th Centuries. (Gutsherr und Bauer in Livland im 17. und 18. Jahrhundert). Strassburg, Trübner. 266 pp. (In German).

Wimmer, C.A. 2001. Trees and Bushes in Historic Gardens: Woodland Use in History and Monument Care. (Bäume und Sträucher in historischen Gärten: Gehölzverwendung in Geschichte und Denkmalspflege). Dresten, Verlag der Kunst. 256 pp. (In German).

\section{Archive sources}

AM 4646:21 G 6930. Gyllenschmidt von, C.O. 1783. Vasula mõis. Estonian History Museum. [WWW document]. URL - http://wWw.muis. ee/en_GB/museaalview/3182852/. [Accessed 30. November 2019].
EAA 1690.1.34 Sheet 1. Pahlen, G.F. 1753. Plan der Hoflage von dem Guthe Palms. (Palmse Manor). Estonian National Archives.

EAA 1.2.C-II-35 Sheet 1. Holmberg, J. 1689. Wiems GenerL: GouverTZ: i Estland Tafelgodz. (Viimsi Manor). Estonian National Archives.

EAA 1.2.C-III-11 Sheet 1. Holmberg, J. 1692. Mardt Hoff I Jegelecht Sochn. (Maardu Manor). Estonian National Archives.

EAA 1.2.C-III-37 Sheet 1. Holmberg, J. 1690. Rasich Hoff i Johannis Sochn beläget. (Raasiku Manor). Estonian National Archives.

EAA 1.2.C-III-41 Sheet 1. Holmberg, J. 1691. Kangla sampt en deel aff Arrokyls Hoffz i Jürgen Sochn. (Aruküla Manor). Estonian National Archives.

EAA 1.2.C-III-50 Sheet 1. Gedhardt, J. 1692. Haneioggi Hoff och Någre Desz ill Höörige Byar i Johannis Sochn. (Anija Manor). Estonian National Archives.

EAA 1.2.C-IV-37 Sheet 1. Gedhardt, J. 1693. Karta över godset Hanejoggi och des gränsar. (Anija Manor). Estonian National Archives.

EAA 1.2.C-IV-196 Sheet 1. Gedhardt, J. 1701. [Matzall Hoff åkerlotter] (Matsalu Manor). Estonian National Archives.

EAA 1.2.C-IV-240 Sheet 1. Waxelberg, S. 1687. Casti Hoff i Merjama Sochn. (Kasti Manor). Estonian National Archives.

EAA 1324.1.141 Sheet 8. Wirtschaftliches Notizbuch. Estonian National Archives.

EAA 46.2.234. Sheet 1. 1769. Grenzkarte der Güter Orgena, Metztacken und Kardina. (Orina Manor). Estonian National Archives.

EAA 46.2.200 Sheet 1. Dankwart, J.H. 1730 Geometrische Charte von dehnen Laendereien Hoff-Lahge, und Söltung des Guttes Uchten, welches in die ... an den Herr Baron v. Wrangele und $\mathrm{H}$. Major v. Ungern geteilet worden. (Uhtna Manor). Estonian National Archives.

EAA 308.2.213 Sheet 1. Swedman, I., Böök, J. 1688. Öfwerpahlens Stätt och Gebiet. (Uhtna Manor). Estonian National Archives (VanaPõltsamaa).

EAA 308.2.186 Sheet 1. Reuter, E. 1688. Gambla Antzen uthi Rappins Gebit och Urbs Kyrckspil. (Vana-Antsla Manor). Estonian National Archives.

EAA 854.4.469 Sheet 32. Löwis of Menar von, K., Waxelberg, S. 1683/mid-19th century. Lode. (Koluvere Manor). Estonian National Archives.

EAA 2072.3.41a Sheet 4 foolio III. Ellram, D., Rosenpflanzer, D. 1851. Charte des im Livländischen Gouvernement, Dörptschen Kreise und Laisschen Kirchspiele publiquen Gutes Schloss Lais. (Laiuse Manor).

EAA 2072.3.426e Sheet 30. 1790. Plan von dem Gut Kangern. (Kangruselja Manor). Estonian National Archives.

EAA.2072.3.426e Sheet 32. 1790. Plan von dem Gut Kangern. (Kangruselja Manor). Estonian National Archives. 
EAA 2072.5.483 Sheet 1. Anders, C. 1808-1809. Specielle Geom. Charte von dem priv. Guthe Wassula. (Vasula Manor). Estonian National Archives.

EAA 2072.5.49 Sheet 1. Henning, F. 1800. Charte von den Hofs Feldern des Gutes Koik. Estonian National Archives.

TÜR KAF 37591. Waxelberg, S. 1680-1690. Historical Art Collection of Photos of University of Tartu Library. Porkuni. (Porkuni linnuse vaated (joonis Stockholmi Sõjaarhiivist)). [WWW document]. - URL http://dspace.ut.ee/handle/10062/37591/. [Accessed 30 November 2019].
TÜR KAF 39024. Waxelberg, S. 1683. Historical Art Collection of Photos of University of Tartu Library. Lihula. (Lihula linnuse vaated Stockholmi Sõjaarhiivist. Kolm joonist: 1. linn ja linnus O-st, 2. linnus O-st, 3. linnus N-st). [WWW document]. - URL https://dspace. ut.ee/handle/10062/39024. [Accessed 30 November 2019].

TÜR KAF 4714. Olearius, A. 1647. Historical Art Collection of Photos of University of Tartu Library, no 4714. Kunda. (Kunda Manor). [WWW document]. - URL https://hdl.handle. net/10062/39218. [Accessed 30 November 2019]. 


\section{Puittaimede kasutamisest 17. sajandi II poole Eesti- ja Liivimaa mõisaansamblites}

\section{Sulev Nurme}

\section{Kokkuvõte}

17. sajandi Eesti-ja Liivimaa pargikunstist ei ole palju teada ega ole sellest palju säilinud. Enamik teadaolevast infost põhineb ajalooliste arhiivi- ja kirjandusallikate kirjeldustel ning mõnedel teada-tuntud gravüüridel. Kirjandusallikate baasil tollast aiakunsti käsitlevates artiklites ja monograafiates on levinud arusaamaks kujunenud, et 17. sajandi aiakunst Eesti mõisates, võrreldes Lääne- ja Kesk-Euroopa maadega, kus sajandi teisel poolel võidutses barokkaed, oli üsna tagasihoidlik nii mastaapides kui ka kujunduskeeles, jäädes lähedaseks pigem hiliskeskaegsele praktikale. Seetõttu oli 17. sajandi turbulentses poliitilises ja majanduslikus situatsioonis vaja keskenduda pigem mõisasüdamete kindlustamisele, mille juures puittaimede kasvatamiseks ahtal kindluselamu õuel ei olnud ruumi ning iluaedade rajamiseks puudusid võimalused ja ka ambitsioon. Süüvides ent 17. sajandi lõpukümnenditest pärinevatesse rootsiaegsetesse mõisaplaanidesse, on põhjust arvata, et barokne aiakunst jõudis ka Rootsi meretagusesse provintsi ning mõjutas Eesti- ja Liivimaa jõukamate mõisasüdamete kujunemist olulisel määral 17. sajandi viimastel kümnenditel enne Põhjasõda. Viiteid üsnagi tähelepanuväärsetes mastaapides rajatud iluaedadele leiab paljudelt rootsiaegsetelt mõisakaartidelt. Tõsi, reduktsiooniga seoses 1681. aastast kuni Põhjasõjani mõõdistatud kaardid ei anna infot detailsete plaanilahenduste kohta, kuid neilt saab sageli välja lugeda mõisasüdame üldise ruumikavatise ning suhted maastikuga.

Kaardianalüüsile toetudes võib öelda, 17. sajandi Eesti- ja Liivimaa mõisasüdamete planeeringutes avaldub selgelt varabaroksetele mõisaansamblitele omane ruumilahendus, mida iseloomustab mõisa peahoone (härrastemaja) esteetilisest diktaadist lähtuv jõuliselt ümber kujundatud maastik. Seda iseloomustab ansambli telgsümmeetriline ruumiline ülesehitus ning eelkõige peahoone kesktelje pikendusel maastikku suunduvad alleed. Sageli on kaartidel loetav baroksele mõisaansamblile iseloomulik ruumiline ülesehitus, mille kohaselt ansambel jaotub kaheks omavahel seotud ruumiüksuseks. Neist ansambli esinduslikuma osa moodustab peahoone ning sellega seotud kõrvalhoonete poolt defineeritud avar väljak peahoone ees ning intiimsem tagaväljak peahoone taga, mille mahust enamiku moodustab ilu- ning tarbeaed.

Artikkel keskendub 17. sajandi II poole Eesti- ja Liivimaa mõisaparkide ruumilisele kompositsioonile, vaadeldes kitsamalt puude kasutamist ja rolli selles. Siinne artikkel põhineb autori tehtud baroksete mõisasüdamete planeeringut käsitleva uuringu "Understanding the Role of 18th Century Estonian Manor Ensembles in Contemporary Planning and Conservation" (Eesti 18. sajandi mõisaansamblid 21. sajandi maastikuplaneerimises: avastamine, mõistmine, tõlgendamine) raames tehtud mõisaansamblite ruumilise struktuuri käsitlevate kaardianalüüside tulemustele ja tähelepanekutele. Artikkel vaatleb puittaimede võimalikke kasutamisviise 17. sajandi viimastel kümnenditel Eesti mõisates, lähtudes mõisaansamblist kui varabaroksest arhitektoonist.

Võib öelda, et 17. sajandi viimastel kümnenditel olid jõukamad mõisad jõudnud välja ehitada tagasihoidliku, kuid selgelt barokse ruumiplaneeringuga mõisasüdamed, mida iseloomustab regulaarse ruumilise planeeringuga ansamblituumik, peahoonega teljeliselt seotud aed ning 
maastikku suunduvad alleed. Puittaimi kasutati loomulikult alleeistutustes, kuid nendega formuleeriti ka iluaedade piirid ning ruumistruktuur. Seejuures nii taimekasutus esteetiliselt kui ka liigiliselt lähtus eeldatavasti toonase Euroopa kaasaegsest praktikast vahendatuna Rootsist. Toetudes Ants Heina käsitlusele 17. sajandi mõisaarhitektuurist (Hein 1998), võib öelda, et suure tõenäosusega oli moodne iluaed ehitatud vähemalt sajakonna barokses võtmes uue hoonestuse saanud mõisasüdame juurde, kuid tõenäoline on, et iluaedadega mõisa- südameid oli rohkem. Kahjuks enamik 17. sajandi aiakunstipärandist hävis Põhjasõjas või ehitati 18. -19. sajandil ümber.

Selline käsitlus võimaldab mõnevõrra laiendada harjumuspärast arusaama tollasest aia- ja pargikunstist Eesti- ning Liivimaa mõisasüdametes. Seetõttu võib artiklis väljatoodu põhjal öelda, et praeguse Eesti maastikupildi vorminud barokne pargikunsti traditsioon ja praktika, sh puittaimede kasutamispõhimõtted mõisaparkide ansambliruumi liigendamisel kujunesid sisuliselt välja juba 17. sajandi lõpuks. 